\title{
Keys to Successful Management of Hearing Impaired Children in India
}

\author{
Priya Shah* \\ Department of Otolaryngology, India
}

Submission: March 20, 2016; Published: March 23, 2017

*Corresponding author: Priya Shah, Department of Otolaryngology, India, Email: priya93shah@gmail.com

Abstract

India is one of the largest developing countries having population of 120 million. As per recent statistics 1 in every 1000 children have severe to profound hearing impairment. More than $60 \%$ of these children reside in the rural area. With the present Growth rate of population, there will be an addition of more than 25000 hearing impaired children every Year.

\section{Role of Government}

Though there are many government aided special schools for these children throughout the country, the most shocking is that, more than $80 \%$ of them still follow gestural/sign language as a main mode of rehabilitation. These government institutes are able to provide only economical analogue hearing aids due to paucity of funds and provides free education and support to them for primary education only.

\section{Present Situation}

Due to non availability of complete rehabilitation programs at these centers, majority of them have poor auditory skills and deliver poor understandable spoken language. More than $70 \%$ of them are not in a position to get integrated into normal schools. Thus these children are left with no option but to stay away from normal society and are not able to peruse secondary education and higher studies. Thus they are forced to do only labour work and the revenue for the same is not sufficient for them to sustain their life span and are always dependant on their families. These groups of children are living with guilt feeling and depression and consider themselves as handicap. The illiteracy, poverty, ignorance and myths and misconceptions have further added fuel to misery of these children.

\section{Our Role/Action}

We have been involved in management of hearing impaired children since last 20 years and we have realized that there is a need to do something different in order to give the maximum benefit of recent advancement of Technology to these children. We also realized that there is complete ignorance about management of these children in our society and also in nongovernmental and governmental organizations. So we devised various multipurpose activity programs, which gave us encouraging results. We want to share our experience with other professionals which we feel will be helpful to various developing countries.

\section{Methodology}

We decided to help these children by focusing into the various areas of concern since last 5 years.

a. Creating Mass Awareness by lectures, distributing posters and information booklets and use of print media

b. Visiting many special schools and understanding their problems.

c. Use of high-tech hearing aids for our private patients and assessing their results.

d. Show casing of our results by elocution competition, personality contest, Dance competition etc.

e. Large support of press and media by writing articles.

f. Forming an association called JOSH which help and guide parents and hearing impaired children.

g. Use of celebrities of bollywood as an Ambasador.

h. Showcase of Hearing Impaired Children having good results to other parents.

i. Creating financial assistance to the needy by joint Contribution methods. 
j. Use of our contacts to share our view point with government authority

k. Convincing non-governmental organizations and others the importance of helping these children.

\section{Results}

Our efforts started giving us a positive response from all sections of society. Many of the special schools have changed from sign language to total aural rehabilitation program. Within a short span many children have been integrated in normal schools. Few of them have already started acquiring professional career and also have gone abroad for higher education The improved auditory and verbal skills have made these children speak the language understandable by all. The society and Non Government Organizations have started increasing support and the government agencies have already started considering our proposal of using high-tech hearing aids and switch over to total aural rehabilitation program.

\section{Conclusion}

We have seen a glow of light rising at horizon for these hearing impaired children. A lot to be done but we feel that the steps which has given us success, if shared with others will make some difference in other developing countries and we may together be able to create global revolution where every one of us can say proudly that, "Hearing handicap no more handicap."

\section{Your next submission with Juniper Publishers will reach you the below assets}

- Quality Editorial service

- Swift Peer Review

- Reprints availability

- E-prints Service

- Manuscript Podcast for convenient understanding

- Global attainment for your research

- Manuscript accessibility in different formats ( Pdf, E-pub, Full Text, Audio)

- Unceasing customer service

Track the below URL for one-step submission https://juniperpublishers.com/online-submission.php 